\title{
Reliability and validity of a Brazilian version of the Hypomania Checklist (HCL-32) compared to the Mood Disorder Questionnaire (MDQ)
}

\section{Confiabilidade e validação da versão brasileira do Questionário de Hipomania (HCL-32 VB) comparado ao Questionário de Transtornos de Humor (MDQ)}

\author{
Odeilton Tadeu Soares, ${ }^{1}$ Doris Hupfeld Moreno, ${ }^{1}$ Eduardo Calmon de Moura, ${ }^{1}$ Jules Angst, ${ }^{2}$ \\ Ricardo Alberto Moreno'
${ }^{1}$ Mood Disorders Unit (GRUDA), Department and Institute of Psychiatry, School of Medicine, Universidade de São Paulo (USP), São Paulo, SP, Brazil
2 Zurich University Psychiatric Hospital, Zurich

\begin{abstract}
Objective: Bipolar disorders are often not recognized and undertreated. The diagnosis of current or past episodes of hypomania is of importance in order to increase diagnostic certainty. The Hypomania Checklist-32 is a self-applied questionnaire aimed at recognizing these episodes. As part of the international collaborative effort to develop multi-lingual versions of the Hypomania Checklist-32, we aimed to validate the Brazilian version and to compare its psychometric properties with those of the Mood Disorder Questionnaire. Method: Adult outpatients with bipolar disorder I $(\mathrm{n}=37)$, bipolar disorder II $(\mathrm{n}=44)$ and major depressive disorder $(n=42)$ of a specialized mood disorder unit were diagnosed according to DSM-IV-TR using a modified version of the SCID. We analyzed the internal consistency and discriminative ability of the Hypomania Checklist-32 Brazilian version in relation to the Mood Disorder Questionnaire. Results: The internal consistency of the Brazilian Hypomania Checklist-32, analyzed using Cronbach's alpha coefficient, was 0.86 . A score of 18 or higher in the Hypomania Checklist-32 Brazilian version distinguished between bipolar disorder and major depressive disorder, with a sensitivity of 0.75 and a specificity of 0.58 , compared to 0.70 and 0.58 , respectively, for the Mood Disorder Questionnaire (score $\geq 7$ ). The Hypomania Checklist-32 Brazilian version showed a dual factor structure characterized by "active/elated" and "risk-taking/ irritable" items. Hence, the Hypomania Checklist-32 Brazilian version was found to have a higher sensitivity but the same specificity as the Mood Disorder Questionnaire. Conclusion: The Brazilian version of the Hypomania Checklist-32 has adequate psychometric properties and helps discriminating bipolar disorder from major depressive disorder (but not bipolar disorder I from bipolar disorder II) with good sensitivity and specificity indices, similar to those of the Mood Disorder Questionnaire.
\end{abstract}

Descriptors: Questionnaire; Major depressive disorder; Bipolar disorder; Diagnosis; Psychometrics

\section{Resumo}

Objetivo: $O$ transtorno bipolar muitas vezes não é reconhecido e deixa de ser tratado adequadamente. O diagnóstico de episódios atuais ou passados é importante, a fim de aumentar a certeza diagnóstica. O Questionário de Autoavaliação de Hipomania-32 é um questionário autoaplicável para o rastreamento desses episódios. Como parte do desenvolvimento em vários idiomas do Questionário de Autoavaliação de Hipomania-32, nós objetivamos validar a versão brasileira e comparar suas propriedades psicométricas com o Questionário de Transtornos do Humor. Método: Em uma unidade especializada em transtornos do humor foram selecionados pacientes ambulatoriais adultos com transtorno bipolar $I(n=37)$, transtorno bipolar II $(N=44)$ e transtorno depressivo maior $(N=42)$ de acordo com a DSM-IV-TR, utilizando uma versão modificada do SCID. Analisou-se a consistência interna e capacidade discriminativa do Questionário de Autoavaliação de Hipomania-32 versão brasileira comparada ao Questionário de Transtornos do Humor. Resultados: A consistência interna do Questionário de Autoavaliação de Hipomania-32 versão brasileira é boa, com alfa de Cronbach 0,86. Um escore de 18 ou mais no Questionário de Autoavaliação de Hipomania-32 versão brasileira distingue entre o transtorno bipolar e o transtorno depressivo maior com uma sensibilidade de 0,75 e especificidade de 0,58, epara o Questionário de Transtornos do Humor, para um escore de 7 ou mais, de 0,70 e 0,58, respectivamente. O Questionário de Autoavaliação de Hipomania-32 mostrou uma estrutura caracterizada pela predominância de dois fatores (ativaçãolelação e irritabilidadel correr riscos). Assim, o Questionário de Autoavaliação de Hipomania-32 versão brasileira tem maior sensibilidade, mas a mesma especificidade que o Questionário de Transtornos do Humor. Conclusão: A versão brasileira do Questionário de Autoavaliação de Hipomania-32 possui propriedades psicométricas adequadas e ajuda a discriminar o transtorno bipolar do transtorno depressivo maior (mas não transtorno bipolar I de transtorno bipolar II), com boa sensibilidade e especificidade, semelhante ao Questionário de Transtornos do Humor.

Descritores: Questionário; Transtorno depressivo maior; Transtorno bipolar; Diagnóstico; Psicometria
Submitted: May 30, 2009

Accepted: June 9, 2010

\section{Correspondence}

Ricardo A. Moreno

Instituto de Psiquiatria

Rua Dr. Ovídio Pires de Campos, 785 - $3^{\circ}$ andar, Ala Norte

05403-010 São Paulo, SP, Brazil

Phone/Fax: (+55 11) 3069-6649

Email: rmoreno@hcnet.usp.br 


\section{Introduction}

Bipolar disorder (BD) is a chronic psychiatric illness that is often misdiagnosed. ${ }^{1}$ Indeed, it may take an average of 10 years from symptom onset to recognition and treatment. ${ }^{2,3}$ It is a burdensome disorder, and even its subsyndromal forms negatively impact social and functional outcomes in adolescents. ${ }^{4,5}$ Accordingly, the identification of patients within the broad bipolar spectrum is of great clinical importance. Consequences of misdiagnosis include worsening of the disease, iatrogenic treatment with antidepressants, increased risk of suicide, alcoholism, drug addiction, risk of contracting sexually transmitted diseases (mainly AIDS), and litigations. ${ }^{6,7}$

Bipolar disorder type II (BD-II) is a common disorder, affecting around $3-5 \%$ of the adult population worldwide, with estimates of up to $11 \%$ for bipolar spectrum disorders. ${ }^{8}$ In Brazil, the lifetime prevalence is $8.3 \%$ for the bipolar spectrum. ${ }^{?}$

Recognition of past episodes of hypomania is pivotal for the diagnosis, although depression is the typically presenting feature of the illness. The under-recognition of hypomania leads to a significant rate of misdiagnosis, with consequent mismanagement, i.e., treatment of $\mathrm{BD}$ as a unipolar disorder. ${ }^{10}$ Because hypomania is often not perceived by patients as pathological, it is not common for them to spontaneously report it to clinicians. ${ }^{11}$ Furthermore, clinicians often do not directly inquire about hypomania if patients are seen during episodes of depression, ${ }^{12}$ despite evidence showing that from $30 \%$ to $60 \%$ of outpatients with BD are initially considered to be unipolar. ${ }^{13}$ This is of great importance, since the long term outcome of BD can be modified by early identification and treatment. ${ }^{14}$

Accordingly, the recognition of hypomania may require more detailed assessments than currently available through structured diagnostic interviews, such as the diagnostic criteria of the DSM$\mathrm{IV} .{ }^{15}$ Indeed, these interviews may be less valid than previously believed. ${ }^{12}$ The DSM-IV diagnostic criteria have high specificity but low sensitivity for the diagnosis of hypomania. It has been proposed that focusing on specific symptoms (e.g., activation), as well as accepting shorter durations of episodes, may improve the recognition of bipolar disorder. ${ }^{4}$ For these reasons, diagnostic tools for hypomania and BD-II are necessary. Several screening instruments have been developed for this purpose. Some of them assess trait-like features (e.g., Hypomanic Personality Scale), ${ }^{16}$ and are better understood as assessing risk factors for future disorders. ${ }^{12}$ These scales assess personality traits rather than the episodic nature of hypomania, and do not evaluate possible changes in affect, cognition, and behavior in bipolar patients. ${ }^{17}$ Other self-report measures have not been proposed as screening instruments, but assess symptoms, such as the Self-Report Inventory for Mania ${ }^{18}$ and the Brief Bipolar Disorder Scale. ${ }^{19}$

The Hypomania Checklist-32 (HCL-32) is an internationally validated self-applied questionnaire. ${ }^{20-25}$ The primary goal of the authors of the HCL-32 is to identify hypomanic components in patients with depression, in order to facilitate the diagnosis of BDII. A secondary goal is the development of shorter multi-lingual versions with established cut-off scores for hypomania. ${ }^{11}$
Accordingly, the aim of this study was to develop a Brazilian version of the HCL-32 (HCL-32 VB), as well as to describe its psychometric characteristics for use in the clinical practice. We also aimed to determine a threshold score with good sensitivity and specificity to detect hypomania. In addition, we contrasted the HCL-32 VB with the Mood Disorder Questionnaire (MDQ), a screening instrument largely used for improving the identification of BD. ${ }^{26}$ Its English version was shown to have a sensitivity of $73 \%$ and a specificity of $90 \%$ for a sample consisting mostly of BD-I patients. In the development study, the MDQ was more efficient in identifying BD-I than BD-II. ${ }^{27}$ Because the HCL-32 has a better focus on hypomanic symptoms, we hypothesized that it could be more adequate to identify bipolarity types I and II.

\section{Method}

The study was conducted at the Mood Disorders Unit (GRUDA) of the Department and Institute of Psychiatry of the School of Medicine, Universidade de São Paulo, Brazil. The study was approved by the Institutional Ethics Committee and consent forms were obtained from all participants.

\section{Subjects}

BD-I, BD-II, and major depressive disorder (MDD) outpatients of both genders $(\mathrm{N}=150)$, aged 18 to 65 years, were selected according to SCID-I/P - DSM-IV diagnoses. Participants were typically chronic and difficult to treat. We included only symptomatic individuals (mania, hypomania, depression), treated or not. Exclusion criteria included uncompensated substance abuse or dependence (except nicotine) over the previous three months, organic mental disorders, and incapacity to understand the questionnaire. Volunteers were assessed by the primary investigator using the SCID-I/P. ${ }^{28}$

\section{Instruments}

The HCL-32 consists of 32 yes/no questions. It is a self-applied questionnaire for the assessment of hypomania that investigates the presence of a variety of symptoms. ${ }^{11}$ Participants are requested to focus on "the 'high' periods" and to indicate whether specific thoughts or emotions were present during this state (including low-threshold symptoms such as "making jokes" and "I am less shy and inhibited" or "I am more flirtatious and/or am sexually more active"). In addition, the HCL-32 includes 8 severity and functional impact items related to the duration of the episodes and to positive and negative consequences across different areas. Participants are asked to rate the impact on family life, social life, school, and leisure, as "positive", "no impact", or "negative." In addition, other people's reactions and comments (positive, neutral or negative) about such episodes are assessed.

The MDQ is a self-rating screening questionnaire for BD-I and II, with questions related to hypomania, validated for use in psychiatric practice ${ }^{2}$ and in the general population. ${ }^{29}$ It consists of 13 questions (yes/no) evaluating mood, self-confidence, energy, sociability, interest in sex, and other behaviors. Two additional questions explore the concomitance of symptoms during any given 
period, as well as the severity of the functional impairment caused by the symptoms. Disability is rated from "no consequences" to "severe consequences". ${ }^{29}$ The MDQ is considered positive when individuals respond "yes" to at least 7 of the 13 items, have at least 2 symptoms occurring simultaneously, and are at least moderately impacted. The Brazilian version of the MDQ is in process of validation by the authors.

The SCID-I/P is the standardized semi-structured clinical interview which provides diagnoses according to the DSM-IVTR. ${ }^{15}$ It was developed by the American Psychiatric Association and is designed for use by clinicians with experience in assessing psychopathology and managing patients. According to it, the diagnosis of hypomania requires at least four days of mood change with euphoria and/or irritability and is a prerequisite for subsequent questioning on manic symptoms. The present study imposed no minimum time limit for hypomania diagnosis, given that the four-day period is in itself arbitrary. ${ }^{21}$ All mania-related questions were asked, even when patients denied mood changes. When this happened, the question on irritable and/or manic mood was asked again at the end of the evaluation in order to increase the detection of bipolarity. ${ }^{25}$

\section{Procedures}

The original version of the HCL-32 was translated and adapted to Brazilian Portuguese according to the World Health Organization instrument translation protocol..$^{30}$ The first draft of the Brazilian version was translated by the authors and reviewed by experts in mood disorders, as well as by a Brazilian Portuguese teacher. It was then back-translated by an English (American) teacher. The same procedure was applied for the MDQ. All eligible patients received instructions to complete both the HCL-32 VB and the MDQ.

\section{Statistical analysis}

Data were entered in summary tables and descriptive statistics. Demographic variables (except gender) were analyzed using analysis of variance (ANOVA) after confirmation of normality and homogeneity of variances. Data related to gender were analyzed using the chi square test, since each frequency was $>5$. In the absence of a normal distribution, we used a nonparametric MannWhitney $U$-test to compare the mean number of positive responses to the HCL-32 BV. To analyze the consistency of the 32 items, we used principal component factor analysis with subsequent varimax rotation. The number of factors was decided in accordance with the Scree test and Monte Carlo Parallel Analysis. Subscale scores for each factor were obtained by summing all items that loaded higher than 0.40 on the corresponding factor. Internal consistency was analyzed using Cronbach's alpha coefficient for the total HCL-32 VB and its subscales. Receiver operating characteristic (ROC) analysis was conducted to distinguish MDD from bipolar patients. Threshold scores in the HCL-32 VB for bipolar patients were calculated. The area under the ROC curve (AUC) was determined as a measure of discriminant predictive value. Associations between the current mental state (HCL-32) and current episode type (DSM-IV) were evaluated using Spearman's correlation. Two-tailed tests with a probability ( $\mathrm{p}$-value) $<0.05$ were considered significant. All statistical analyses were performed using the Statistical Package for the Social Sciences (SPSS). ${ }^{31}$

\section{Results}

\section{Sample size and demographic variables}

The HCL-32 VB was completed by 150 patients. The sample size was established so that the total number of patients was approximately five times the number of items ${ }^{32}$ in the HCL-32, and adequately powered (0.944) to conduct a factor analysis and assess the sensitivity and specificity of the instrument. For an estimated power of 0.85 , we would need 31 patients in each diagnosis. Of 150 individuals enrolled, 27 were excluded; 11 due to substance abuse and 16 due to inability to complete the questionnaires properly. Such inability was mostly related to their low educational level and not to cognitive impairment associated with mania, hypomania or depression. Accordingly, our final sample comprised 81 patients with BD (37 BD-I; 44 BD-II) and 42 with MDD. No significant differences were found in relation to age or gender (Table 1).

\section{Translation and adaptation}

The Brazilian version of the HCL-32 was approved by the authors of the original version and was named HCL-32 VB (Appendix 1 - see at www.scielo.br/rbp). The Brazilian version of the MDQ was named MDQ VB (Appendix 2 - see at www. scielo.br/rbp).

Feasibility was described as the percentage of patients $(n=12)$ who did not complete the entire questionnaire (8\% left at least one question unanswered). Internal consistency was high, with a Cronbach's alpha coefficient of 0.86 for the entire HCL-32 VB, indicating that the items of the questionnaire were sufficiently homogeneous. The exclusion of individual items did not affect Cronbach's alpha. The factor analysis resulted in 9 factors with eigenvalues $>1$, explaining $61.6 \%$ of the total variance. According to the Scree test and Monte Carlo Parallel Analysis, a 2-factor solution was preferred.

The first factor, with an eigenvalue of 6.79 , explained $21.2 \%$ of the variance and comprised 20 items (Table 2). This subscale

Table 1 - Mean age and sex distribution among bipolar I and II and MDD patients in the Brazilian Version of the HCL-32

\begin{tabular}{|c|c|c|c|c|c|}
\hline & $\begin{array}{c}\text { Total } \\
(\mathrm{N}=123)\end{array}$ & $\begin{array}{c}\text { BD-I } \\
(\mathrm{N}=37)\end{array}$ & $\begin{array}{c}\text { BD-II } \\
(N=44)\end{array}$ & $\begin{array}{c}\text { MDD } \\
(\mathrm{N}=42)\end{array}$ & $p$ \\
\hline Women & $78.9 \%$ & $81.1 \%$ & $75 \%$ & $81 \%$ & 0.736 \\
\hline Mean age & $42(S D=11.1)$ & $41(S D=11.3)$ & $43(S D=11.3)$ & $40(S D=10.9)$ & 0.405 \\
\hline
\end{tabular}


Table 2 - Factor structure of the HCL-32 Brazilian Version after varimax rotation in bipolar I, bipolar II, and MDD patients

\begin{tabular}{|c|c|c|}
\hline \multirow[t]{2}{*}{ Item description } & \multicolumn{2}{|c|}{ Factors } \\
\hline & 1 ("active-elated") & 2 ("irritable/risk-taking") \\
\hline I talk more & 0.647 & -0.018 \\
\hline I want to meet or actually met more people & 0.645 & 0.092 \\
\hline I make more jokes & 0.615 & 0.125 \\
\hline I engage in lots of new things & 0.607 & -0.139 \\
\hline I think faster & 0.587 & 0.159 \\
\hline I am physically more active & 0.584 & -0.280 \\
\hline I am more flirtatious or more sexually active & 0.583 & -0.059 \\
\hline I am more sociable & 0.538 & -0.299 \\
\hline My mood is higher, more optimistic & 0.533 & -0.336 \\
\hline I have more ideas, I am more creative & 0.523 & -0.135 \\
\hline I take more risks in my daily life & 0.523 & 0.279 \\
\hline I wear more colorful and more extravagant clothes & 0.522 & -0.003 \\
\hline I am less shy or inhibited & 0.521 & -0.094 \\
\hline I am more interested in sex & 0.515 & -0.022 \\
\hline I plan more activities or projects & 0.515 & -0.280 \\
\hline I fell more energetic and more active & 0.502 & -0.176 \\
\hline I enjoy my work more & 0.498 & -0.335 \\
\hline My thoughts jump from topic to topic & 0.494 & 0.360 \\
\hline I want to travel and/or do travel more & 0.439 & -0.280 \\
\hline I do things more quickly and/or more easily & 0.417 & -0.174 \\
\hline I am more easily distracted & 0.388 & 0.182 \\
\hline I need less sleep & 0.376 & 0.189 \\
\hline I am more self-confident & 0.358 & -0.170 \\
\hline I tend to drive faster or take more risks & 0.306 & 0.254 \\
\hline I take more drugs & -0.021 & 0.635 \\
\hline I smoke more cigarettes & 0.068 & 0.601 \\
\hline I am more impatient and/or get irritable more easily & -0.018 & 0.574 \\
\hline I can be exhausting or irritating for others & 0.297 & 0.557 \\
\hline I get into more quarrels & 0.300 & 0.498 \\
\hline I spend more money/to much money & 0.318 & 0.490 \\
\hline I drink more alcohol & 0.230 & 0.445 \\
\hline I drink more coffee & 0.159 & 0.371 \\
\hline
\end{tabular}

Extraction method: Principal Component Analysis.

Two factors extracted.

consisted of questions related to "active/elated" symptoms. The second factor, with an eigenvalue of 3.31 (10.34\% of the variance), comprised 7 items and included questions associated with "irritable/risk-taking" items. For individual items, a factor loading $\geq 0.40$ suggested significant item factors. The factor structure resembled that obtained for other samples of non-clinical subjects and patients with affective disorders in previous studies. ${ }^{11,20,22}$

Individuals with BD had the highest HCL-32 VB scores. The mean number of affirmative responses to the list of symptoms was significantly different according to diagnosis. We analyzed the scale's discrimination of BD through the ROC curve. The area under the curve of the HCL-32 BV was 0.702, indicating a good discriminant ability (Figure 1). The best combination of sensitivity $(0.75)$ and specificity $(0.58)$ was established with a score above 18 , which discriminates between BD and MDD patients. To compare the discriminant properties of the HCL-32 VB and the MDQVB, we calculated the sensitivity and specificity of both questionnaires. The ROC curve of the MDQ VB is shown in Figure 2. The HCL-32 VB had a sensitivity of 0.75 and specificity of 0.58 . The MDQ VB had a sensitivity of 0.70 and specificity of 0.58 . Hence, the HCL-32 VB showed a higher sensitivity but the same specificity as the MDQ VB. Spearman's correlation was 
ROC CURVE (HCL-32 VB)

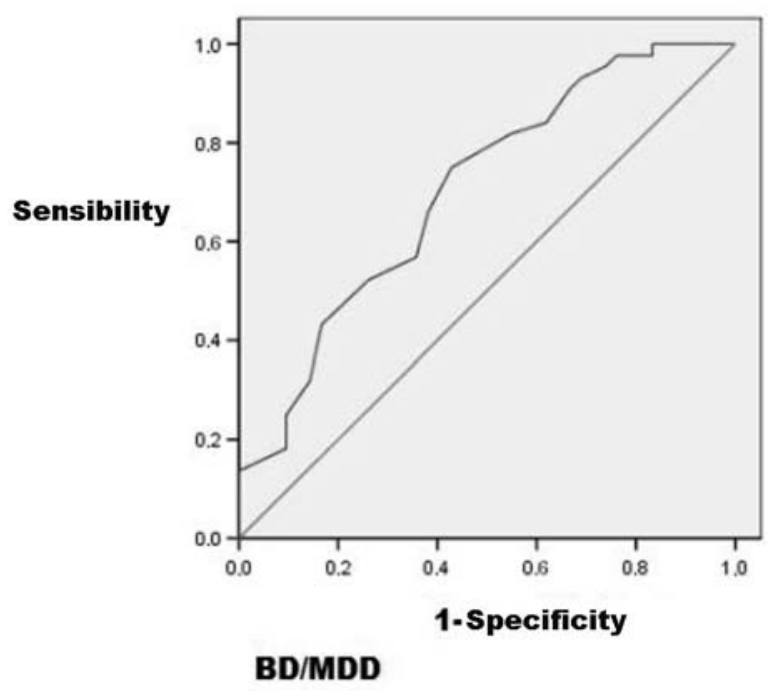

Figure 1 - ROC curve showing the power of HCL-32 total scores to discriminate between bipolar disorder (BD) and major depressive disorder (MDD)

used to correlate current mood state and the HCL-32 total and subscale scores. There was no impact on the self-assessment of hypomanic symptoms $(\mathrm{p}=0.861)$. Significant differences were found for the two subscales between BD-II and MDD, but not between BD-I and BD-II, and no differences were found between $\mathrm{BD}-\mathrm{I}$ and MDD when using the subscale of the first dimension, composed of 20 items (Table 3).

\section{Discussion}

The recognition of hypomania is pivotal for the diagnosis of BD-II. Because hypomania is often not perceived by patients as

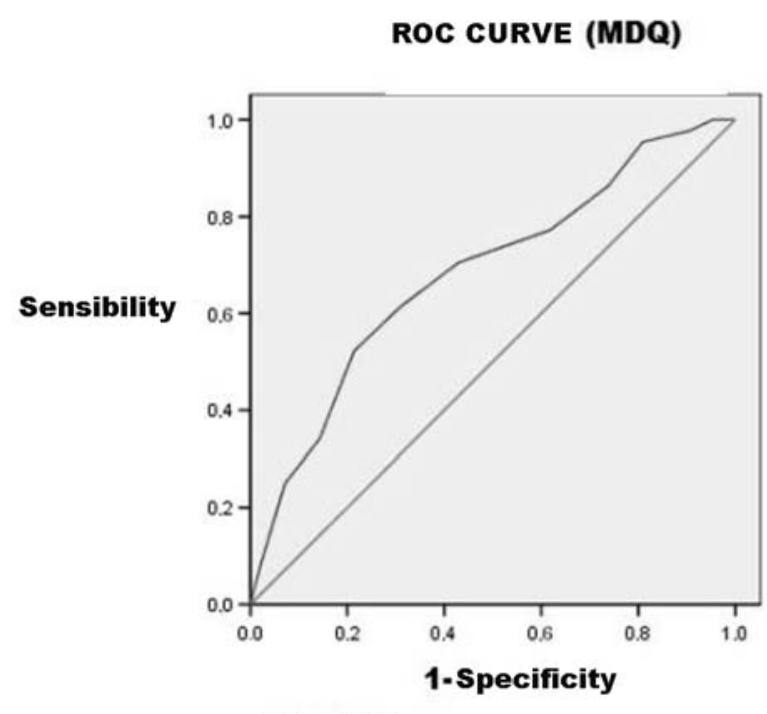

BD/ MDD

Figure 2 - ROC curve showing the power of MDQ total scores to discriminate between bipolar disorder (BD) and major depressive disorder (MDD)
Table 3 - Multiple comparisons: differences between diagnoses

\begin{tabular}{|c|c|c|c|}
\hline & & & $\mathbf{p}$ \\
\hline \multirow[t]{6}{*}{ Factor 1 (ANOVA) } & TBI & TBII & 0.520 \\
\hline & & $\mathrm{DM}$ & 0.288 \\
\hline & TBII & TBI & 0.520 \\
\hline & & $\mathrm{DM}$ & 0.021 \\
\hline & DM & TBI & 0.288 \\
\hline & & TBII & 0.021 \\
\hline \multirow[t]{6}{*}{ HCL32 VB (ANOVA) } & TBI & TBII & 0.567 \\
\hline & & DM & 0.025 \\
\hline & TBII & TBI & 0.567 \\
\hline & & $\mathrm{DM}$ & 0.001 \\
\hline & $\mathrm{DM}$ & TBI & 0.025 \\
\hline & & TBII & 0.001 \\
\hline \multirow[t]{4}{*}{ Factor 2 (Mann-Whitney) } & TBI & TBII & 0.988 \\
\hline & & $\mathrm{DM}$ & 0.000 \\
\hline & TBII & TBII & 0.988 \\
\hline & & DM & 0.000 \\
\hline
\end{tabular}

pathological, it is not common for them to spontaneously report it to clinicians. The recognition of hypomania may require more subtle inquiries than those present in currently available structured diagnostic interviews, such as those based on DSM-IV criteria. Instruments assessing hypomania may be of importance for the clinical practice in Portuguese-speaking countries like Brazil.

Our study included patients with BD-I, BD-II and MDD. We found that the HCL-32 VB had good sensitivity (0.75) and specificity (0.58) with a cut-off score of 18 , meaning that 18 affirmative answers have good discriminatory power to distinguish $\mathrm{BD}$ from unipolar disorder. This differs from the cut-off point (14-15) found in studies conducted in other languages. ${ }^{4,21-24}$ These differences can be explained by the fact that the sample was derived from a tertiary care facility, characterized by patients with greater chronicity and more resistant to treatment. The criterion of 18 affirmative responses to hypomanic symptoms in the HCL-32 VB is sensitive enough to alert healthcare providers about the presence of bipolar disorder. Once aware, clinicians should proceed to a more detailed psychiatric assessment in order to establish a definitive diagnosis.

When compared with the MDQ (sensitivity $=0.70 /$ specificity $=0.58)$, the HCL-32 VB and the HCL-32 are more sensitive to detect hypomanic symptoms. The patients enrolled in our study were symptomatic (mania or hypomania and depression). The correlation analysis showed no association between current mood state and self-assessment of hypomanic symptoms. Internal consistency (Cronbach's alpha of 0.86 ) was high and similar to values found in the validation of the HCL-32 for other languages. ${ }^{11,20,22-24}$ It was comparable to other instruments such as the MDQ. ${ }^{26,29}$ This reliability is similar to values found in samples of remitted patients (Italy, Spain, and Sweden) ${ }^{11,20}$ and also in the general population (Germany and Sweden). ${ }^{33}$ This indicates stable psychometric properties, regardless of clinical status or cultural differences. 
The factor structure also resembled that obtained with other samples of patients with affective disorders in previous studies. ${ }^{11,20}$ A single factor load responded for $21,2 \%$ of the total variance. There is a greater possibility of bipolarity when high scores are detected in two factors, such as increased activation/elation and irritability/risk-taking behavior. The first factor (increase in activity, energy, social contacts, verbal fluency, self-confidence, and communication) relates to activation/increase in energy, while the other factor is related to disinhibition, self-control, and ability to focus (irritability, inattention, difficulties with impulse control, and excessive spending). We confirmed the presence of these two factors and, therefore, high scores in these factors are suggestive of bipolarity. The presence of subsyndromal symptoms of hypomania, such as "wear more colorful and more extravagant clothes, or make more jokes", increases the possibility of BD, but also of more false-positive results.

An interesting finding of our study was the high proportion of patients with MDD (42.9\%) who scored positive in 18 or more questions, which was similar to results obtained in the large international BRIDGE study (data not yet published referring to 2729 subjects with major depressive episodes). ${ }^{33}$ This finding could be related to the fact that the sample was recruited among patients of a tertiary care facility, characterized by greater chronicity and treatment resistance, which can be considered as risk factors for bipolarity. ${ }^{1}$ When used in another sample with more severe mood disorders, the cut-off score of the HCL-32 was also higher, and even after accurate screening for recurrent MDD, almost $18 \%$ had manic symptoms at a level similar to that of BD patients. ${ }^{27}$ Another possible explanation is that some symptoms of hypomania (soft bipolarity) may be present even in clinically undisputable "unipolar" patients. ${ }^{34}$ The DSM-IV criteria do not seem to distinguish the presence or absence of bipolarity. The diagnosis of hypomania is a key aspect in the diagnosis of $\mathrm{BD}$, and this questionnaire provides a potential aid to clinicians. Its use may translate into earlier diagnosis and treatment. Further studies are needed to evaluate the cut-off for other samples of non-clinical subjects or patients with less severe affective disorders.

\section{Limitations}

Although the parameters found for the HCL-32 VB were robust, further studies are needed to evaluate the concurrent and discriminant validity, and the factor structure of the instrument. Furthermore, our study reflects parameters assessed in a tertiary care setting. A comparison with similar samples, before the application in patients, should be performed in future studies, both for the HCL-32 VB and the MDQ. This pioneering study is proposed to establish initial points for validation. Further studies can complement the process of validation of the HCL-32 VB. Moreover, other psychometric properties of the Brazilian version of the HCL-32, such as long-term test-retest reliability, remain to be evaluated in future research.

\section{Conclusion}

The HCL-32 is the first instrument developed for the selfassessment of hypomanic symptoms in patients diagnosed with depression. ${ }^{35}$ The retrospective detection of hypomania is critical for the correct diagnosis and, hence, for the treatment of BD. The psychometric parameters of the HCL-32 VB suggest that it is useful for the detection of hypomania in patients with mood disorders. A cut-off of 18 showed the best trade-off between sensitivity and specificity values. For screening tools, high sensitivity should not be traded-off by high specificity. ${ }^{36}$

The HCL-32 VB may be useful for the identification of hypomania in Brazilian epidemiological and clinical settings, facilitating the early identification of patients within the bipolar spectrum. The HCL-32 VB is a brief, self-administered questionnaire of easy application and interpretation, which can be used in Portuguese-speaking patients. 
Disclosures

\begin{tabular}{|c|c|c|c|c|c|c|c|}
\hline $\begin{array}{c}\text { Writing group } \\
\text { member }\end{array}$ & Employment & $\begin{array}{l}\text { Research } \\
\text { grant }^{1}\end{array}$ & $\begin{array}{l}\text { Other research grant or } \\
\text { medical continuous } \\
\text { education }^{2}\end{array}$ & $\begin{array}{l}\text { Speaker's } \\
\text { honoraria }\end{array}$ & $\begin{array}{l}\text { Ownership } \\
\text { interest }\end{array}$ & $\begin{array}{c}\text { Consultant/ } \\
\text { Advisory } \\
\text { board }\end{array}$ & Other $^{3}$ \\
\hline $\begin{array}{l}\text { Odeilton Tadeu } \\
\text { Soares }\end{array}$ & $\begin{array}{c}\text { USP } \\
\text { Private practice }\end{array}$ & - & - & - & - & - & - \\
\hline $\begin{array}{l}\text { Doris Hupfeld } \\
\text { Moreno }\end{array}$ & $\begin{array}{c}\text { USP } \\
\text { Private practice }\end{array}$ & - & - & $\begin{array}{c}\text { Abbott } \\
\text { AstraZeneca }\end{array}$ & - & $\begin{array}{c}\text { Abbott } \\
\text { AstraZeneca }\end{array}$ & - \\
\hline Jules Angst & $\begin{array}{c}\text { Zurich University } \\
\text { Psychiatric } \\
\text { Hospital }\end{array}$ & - & - & - & - & - & - \\
\hline $\begin{array}{l}\text { Ricardo Alberto } \\
\text { Moreno }\end{array}$ & $\begin{array}{c}\text { USP } \\
\text { Private practice }\end{array}$ & FAPESP* & $\begin{array}{c}\text { BMS }^{\star \star} \\
\text { AstraZeneca** } \\
\text { Servier**}\end{array}$ & - & - & $\begin{array}{c}\text { CEIP } \\
\text { ABTB } \\
\text { ABP } \\
\text { A. Lopes } \\
\text { Munis } \\
\text { Advogados } \\
\text { Mattos Muriel } \\
\text { Kestener } \\
\text { Advogados }\end{array}$ & $\begin{array}{c}\text { Segmento } \\
\text { Farma } \\
\text { Editoras } \\
\text { Artmed } \\
\text { Editora AS. } \\
\text { Lopso } \\
\text { Editora } \\
\text { Editora } \\
\text { Planmark } \\
\text { DOC Editora. } \\
\text { Phoenix } \\
\text { Comunicação } \\
\text { Integrada } \\
\text { Solução }\end{array}$ \\
\hline
\end{tabular}

* Modest

** Significant

*** Significant: Amounts given to the author's institution or to a colleague for research in which the author has participation, not directly to the author. Note: USP = Universidade de São Paulo; FAPESP = Fundação de Amparo à Pesquisa do Estado de São Paulo; BMS = Bristol-Myers Squibb; CEIP = Centro de Estudos do Instituto de Psiquiatria; $A B T B=$ Associação Brasileira de Transtomo Bipolar; ABP; Associação Brasileira de Psiquiatria. For more information, see Instructions for Authors.

\section{References}

1. Goodwin FK, Jamison KR. Manic-depressive illness: bipolar disorders and recurrent depression. 2nd ed. New York: Oxford University Press; 2007.

2. Hirschfeld RM, Calabrese JR, Weissman MM, Reed M, Davies MA, Frye MA, Keck PE Jr, Lewis L, McElroy SL, McNulty JP, Wagner KD. Screening for bipolar disorder in the community. J Clin Psychiatry. 2003;64(1):53-9.

3. Suppes T, Leverich GS, Keck PE, Nolen WA, Denicoff KD, Altshuler LL, McElroy SL, Rush AJ, Kupka R, Frye MA, Bickel M, Post RM. The Stanley Foundation Bipolar Treatment Outcome Network. II. Demographics and illness characteristics of the first 261 patients. J Affect Disord. 2001;67(1-3):45-59.

4. Angst J, Gamma A, Benazzi F, Ajdacic V, Eich D, Rossler W. Diagnostic issues in bipolar disorder. Eur Neuropsychopharmacol. 2003;13 Suppl 2:S43-50.

5. Lewinsohn PM, Gotlib IH, Seeley JR. Adolescent psychopathology: IV. Specificity of psychosocial risk factors for depression and substance abuse in older adolescents. J Am Acad Child Adolesc Psychiatry. 1995;34(9):1221-9.

6. Dunner DL. Clinical consequences of under-recognized bipolar spectrum disorder. Bipolar Disord. 2003;5(6):456-63.

7. Calabrese JR, Hirschfeld RM, Reed M, Davies MA, Frye MA, Keck PE, Lewis L, McElroy SL, McNulty JP, Wagner KD. Impact of bipolar disorder on a U.S. community sample. J Clin Psychiatry. 2003;64(4):425-32.

8. Berk M, Dodd S. Bipolar II disorder: a review. Bipolar Disord. 2005;7(1):11-21.

9. Moreno DH, Andrade LH. The lifetime prevalence, health services utilization and risk of suicide of bipolar spectrum subjects, including subthreshold categories in the Sao Paulo ECA study. J Affect Disord. 2005;87(23):231-41.

10. Scott J. Overcoming mood swings. London: Constable Robinson; 2002. p.21-36. 11. Angst J, Adolfsson R, Benazzi F, Gamma A, Hantouche E, Meyer TD, Skeppar P, Vieta E, Scott J. The HCL-32: towards a self-assessment tool for hypomanic symptoms in outpatients. J Affect Disord. 2005;88(2):217-33.
12. Angst J, Gamma A, Benazzi F, Ajdacic V, Eich D, Rossler W. Toward a redefinition of subthreshold bipolarity: epidemiology and proposed criteria for bipolar-II, minor bipolar disorders and hypomania. J Affect Disord. 2003;73(1-2):133-46.

13. Akiskal HS. The bipolar spectrum--the shaping of a new paradigm in psychiatry. Curr Psychiatry Rep. 2002;4(1):1-3.

14. Lish JD, Dime-Meenan S, Whybrow PC, Price RA, Hirschfeld RM. The National Depressive and Manic-depressive Association (DMDA) survey of bipolar members. J Affect Disord. 1994;31(4):281-94.

15. American Psychiatric Association. Diagnostic and statistical manual of mental disorders. Washington (DC): American Psychiatric Association; 1994,.

16. Eckblad M, Chapman LJ. Development and validation of a scale for hypomanic personality. J Abnorm Psychol. 1986;95(3):214-22.

17. Meyer TD, Hautzinger M. Screening for bipolar disorders using the Hypomanic Personality Scale. JAffect Disord. 2003;75(2):149-54.

18. Shugar G, Schertzer S, Toner BB, Di Gasbarro I. Development, use, and factor analysis of a self-report inventory for mania. Compr Psychiatry. 1992;33(5):325-31.

19. Dennehy EB, Suppes T, Crismon ML, Toprac M, Carmody TJ, Rush AJ. Development of the Brief Bipolar Disorder Symptom Scale for patients with bipolar disorder. Psychiatry Res. 2004;127(1-2):137-45.

20. Vieta E, Sanchez-Moreno J, Bulbena A, Chamorro L, Ramos JL, Artal J, Pérez F, Oliveras MA, Valle J, Lahuerta J, Angst J; EDHIPO (Hypomania Detection Study) Group. Cross validation with the mood disorder questionnaire (MDQ) of an instrument for the detection of hypomania in Spanish: the 32 item hypomania symptom check list (HCL-32). J Affect Disord. 2007;101(1-3):43-55.

21. Angst J. The emerging epidemiology of hypomania and bipolar II disorder. $J$ Affect Disord. 1998;50(2-3):143-51.

22. Wu YS, Ou CS, Chen HC, Lu RB, Angst J. Validation of the Chinese ver sion of the Hypomania Checklist (HCL-32) as an instrument for 
detecting hypomania in patients with mood disorders. J Affect Disord. 2008;106(1-2):133-43.

23. Carta MG, Hardoy MC, Cadeddu M, Murru A, Campus A, Morosini P, Gamma A, Angst J. The accuracy of the Italian version of the Hypomania Checklist (HCL-32) for the screening of bipolar disorders and comparison with the Mood Disorder Questionnaire (MDQ) in a clinical sample. Clin Pract Epidemiol Ment Health. 2006;2:2.

24. Benazzi F. Toward better probing for hypomania of bipolar II disorder by using Angst's checklist. Int J Meth Psychiatr Res. 2004;13(1):1-9.

25. Holtmann M, Pörtner F, Duketis E, Flechtner H, Angst J, Lehmkuhl H. Validation of the Hypomania Checklist (HCL-32) in a nonclinical sample of German adolescents. J Adolesc. 2009;32(5):1075-88.

26. Hirschfeld RM, Holzer C, Calabrese JR, Weissman M, Reed M, Davies M, Frye MA, Keck P, McElroy S, Lewis L, Tierce J, Wagner KD, Hazard E. Validity of the mood disorder questionnaire: a general population study. Am J Psychiatry. 2003;160(1):178-80.

27. Forty L, Smith D, Jones L, Jones I, Caesar S, Fraser C, Gordon-Smith K, Craddock N. Identifying hypomanic features in major depressive disorder using the hypomania checklist (HCL-32). J Affect Disord. 2009;114(1-3):68-73.

28. First MB, Spitzer RL, Gibbon M, Williams JBW. Structured Clinical Interview for DSM-IV Axis I Disorders: Patient Edition, Version 2.0 (SCID-I/P). New York: Biometrics Research Department; 2005.

29. Hirschfeld RM, Williams JB, Spitzer RL, Calabrese JR, Flynn L, Keck PE Jr, Lewis L, McElroy SL, Post RM, Rapport DJ, Russell JM, Sachs GS, Zajecka J. Development and validation of a screening instrument for bipolar spectrum disorder: the Mood Disorder Questionnaire. Am J Psychiatry. 2000;157(11):1873-5.

30. World Health Organization - WHO. Process of translation and adaptation of instruments [Online]; [cited 2009 Jul 15]. Available from: http:// www.who.int/substance

31. SPSS Version 14.0 for windows. Chicago, IL, USA: SPSS Inc; 2007.

32. Casas Anguita J,Ramón Repullo Labrador J, Pereira Candel J. Measurements of quality of life related with health. Basic concepts and cultural adaptation. Med Clin (Barc). 2001;116(20):789-96.

33. Angst J, Azorin JM, Bowden CL, Perugi G, Vieta E, Young AH. Detecting bipolar disorder in patients with a current major depressive episode: interim analysis from an international cross-sectional study. The Ninth International Review of Bipolar Disorders (IRBD) 2009 May 6-8; Lisbon, Portugal (Abstract).

34. Akiskal HS. Validating 'hard' and 'soft' phenotypes within the bipolar spectrum: continuity or discontinuity? J Affect Disord. 2003;73(1-2):1-5.

35. Meyer TD, Hammelstein P, Nilsson LG, Skeppar P, Adolfsson R, Angst J. The Hypomania Checklist (HCL-32): its factorial structure and association to indices of impairment in German and Swedish nonclinical samples. Compr Psychiatry. 2007;48(1):79-87.

36. Zimmermann M, Posternak MA, Chelminski I, Solomon DA. Using questionnaires to screen for psychiatric disorders: a comment on a study of screening for bipolar disorder in the community. J Clin Psychiatry. 2004;65(5):605-10. 


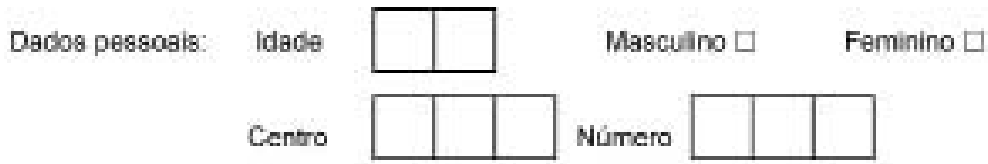

\section{Energia, Atividade o Humor}

Em dlerentes periodos durante a vidg vobos sentem mudanças ou osclaçoes em energia, atividade e humor ("altos e baixos" ou "para cirna e para baixo") O objetwo deste questionário é a de avaliar as caracteristicas dos periodos "altos' ou "para cims".

1) Antes de tudo, como vocs math se anntinde heie comparado ao seu estado habitual ?

(Por favor, marque spenss UM dos seguinfes)

\begin{tabular}{|c|c|c|c|c|c|c|}
\hline $\begin{array}{l}\text { Muta piar do } \\
\text { que } 0 \\
\text { habilual }\end{array}$ & $\begin{array}{c}\text { Plor do que o } \\
\text { habitual }\end{array}$ & $\begin{array}{l}\text { Um pouco } \\
\text { pior do que o } \\
\text { habitual }\end{array}$ & $\begin{array}{c}\text { Nem melhor } \\
\text { nem pior do } \\
\text { que o } \\
\text { habitual }\end{array}$ & $\begin{array}{c}\text { Um pouco } \\
\text { meihor do } \\
\text { que o } \\
\text { habitual }\end{array}$ & $\begin{array}{l}\text { Melhor do } \\
\text { que } 0 \\
\text { habitual }\end{array}$ & $\begin{array}{c}\text { Muto melhar } \\
\text { do que o } \\
\text { habilual }\end{array}$ \\
\hline
\end{tabular}

2) Como vece e normaimente. comparado com outras cessoas?

Independente de como vocé se sente hoje, per favor, conle-nos como vocé é normalmente comparado a outras pesscas, marcando qual dos seguintes enunciados melhor o descreve.

Comparando com cutras pessoss meu nivel de atividade, energia e humor.

(For favor, merque somiente UW dos seguintes)
... sempre sào mais para estavais a equilibredos

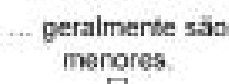
... repetidamente exbem
periodos de altos 6 backos

3) Por fawor, tente lembrar de um periodo em que voch esteme num estado "para cima".

Como voces se aentia na época?

Por favor, respanda a todos estes enunciados, independente do seu estado atual

Em tal estado:

1. Eu precisaug de menos gono

2. Eu me sentia com mais energis e mais ativo (a)

3. Eu estava mais autocorriante

4. Eu apreciava mais o meu trabalho

5 Eu estava mais scoidunel (fazia mais ligaçbes talafónicas, saia mais)

6. Eu queria viajar ou visjava mais

7. Eu tinha tendencia a dirigir mais rápido ou me arriscar mais enquanto dirijia

8. Eu gastava mais ou gastava dinheiro demais

9. Eu me arnscava mais om minha vida diaria (no meu trahalho eibu outras atividades)

10. Eu estava fisicamente mais ativo (a) (esporte, ebc)

11. Eu planejava mais atwidades e projetos

12. Eu tinha mais ideias, eu estava mais criativo (a)

13. Eu ficava menos timido (a) ou initida (a)

14. Eu usava raupas/maquiagem mais ccioridas e extravagantes

15. Eu queria encontrar ou de fato me encontrava com meis pessoss

16. Eu estava mais interessado (a) em sexo eiou tinh desejo sexual aumentado

17. Eu paqueravs mais a/ou estawa sexusimente mais a5vo (a)

18. Eu falava mais

19. Eu penaava mais rapido

20. Eu fazia mais piadas ou trocadihos quando falava

21. Eu me distraia com mais faclidede

22 . Eu me erwolvia em muitas coisas novas

23. Meus pensamentas pulavam de assunto rapidamente

24. Eu fazia coisas mais rapidarnente ejou com maior facilidade

25. Eu ficerva meia impaciente e/ou ficave irrzado (e) mais tacilmente

26. Eu podia ser cansativo (a) ou irrtante para co outros

27. Eu me envolvia em mais discussóes e disputas

28. Meu humar estava melhor, mais ctimista

$\begin{array}{ll}\text { Sim } & \text { Nas } \\ \square & \square \\ \square & \square \\ \square & \square \\ \square & \square \\ \square & \square \\ \square & \square \\ \square & \square \\ \square & \square \\ \square & \square \\ \square & \square \\ \square & \square \\ \square & \square \\ \square & \square \\ \square & \square \\ \square & \square \\ \square & \square \\ \square & \square \\ \square & \square \\ \square & \square \\ \square & \square \\ \square & \square \\ \square & \square \\ \square & \square \\ \square & \square \\ \square & \square \\ \square & \square \\ \square & \square \\ \square & \square\end{array}$


Em tal estado:

29. Eu bebia mais cate

30. Eu fumava meis cigarros

31. Eu betis mais ślcool

32. Eu usava mais drogas (sedafivos, ansioliticos, estimulantes, entre outros)

4) O impacto doa saus 'altos' em varios aspectca de sua vida foŕ:

\begin{tabular}{|c|c|c|c|c|}
\hline & $\begin{array}{c}\text { Postivo e } \\
\text { negalivo }\end{array}$ & Poelivo & Negativo & $\begin{array}{l}\text { Nenhum } \\
\text { impacto }\end{array}$ \\
\hline $\begin{array}{l}\text { Vida familar } \\
\text { Vida social }\end{array}$ & 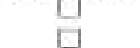 & U & 문 & 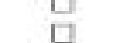 \\
\hline Trabalho & 口 & ㅁ & 口 & 口 \\
\hline Lezer & ㅁ & ㅁ & 口 & 무 \\
\hline
\end{tabular}

5) Qual foi a reaçia e os comentarias das pessoas sabre seus "altos":

Como as pessces probimas a voch reagram ou comantaram seus "ahos"?

(For favor, marque UM dos seguintes)

\begin{tabular}{|c|c|c|c|c|}
\hline $\begin{array}{c}\text { Positivamente } \\
\text { (encorajando ou } \\
\text { 8poiando) }\end{array}$ & Neutros & $\begin{array}{c}\text { Negativamente } \\
\text { (preocupadas, } \\
\text { aborrecidas, Irrtadas, } \\
\text { criticas) }\end{array}$ & $\begin{array}{c}\text { Positivamente } \\
\text { e } \\
\text { nogativamente } \\
\end{array}$ & $\begin{array}{c}\text { Nenhuma } \\
\text { reaçaso }\end{array}$ \\
\hline
\end{tabular}

6) Via de regra, qual fol a duraç5o de 8eus "altor" \{em média\}:

(Por favor, marque UM dos seguintes)

$\begin{array}{ll}\square 1 \text { dia } & \text { Dmaior que } 1 \text { semaria } \\ \square 2-3 \text { dies } & \text { Omaior quo } 1 \text { masa } \\ \square 4-7 \text { dies } & \square \text { Nä posso julgarl năo sęi }\end{array}$

7) Voce sentu tais "altos" nos útimos doze meses?

$\mathrm{Sm} \square \quad \mathrm{NaO}$

8) Se sim,

Por favor, estime quantos das vook passou nestes 'altos" durente oe últimos daze meses.

Levando todos em conts fol de cerca de

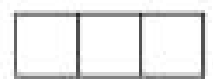

dias 


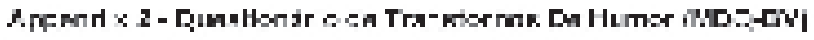

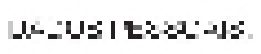

IULLE: - -

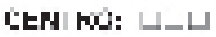

IP.|대여:

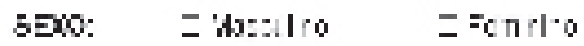

FEGISTS HE:

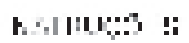

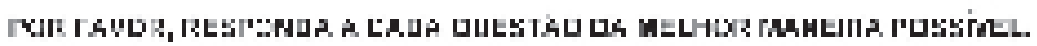

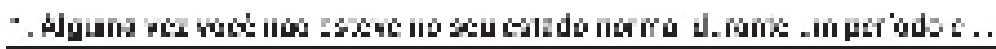

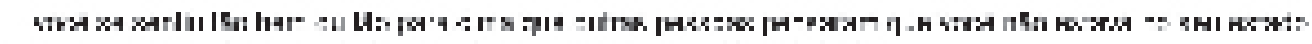

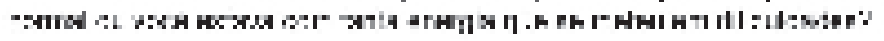

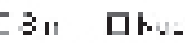

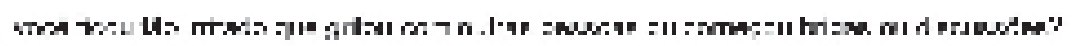

= 3 ॥ ㅁ.

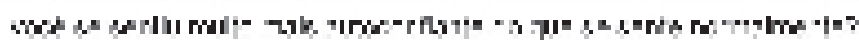

SII I I H.

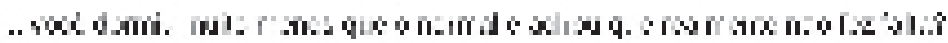

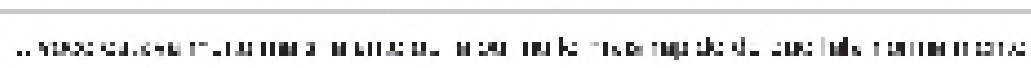

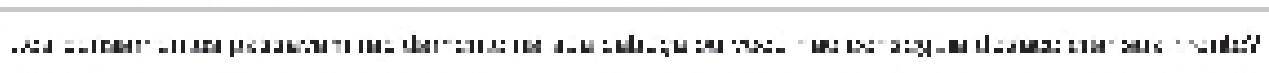

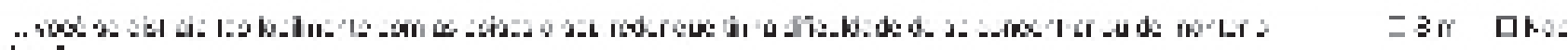
tin

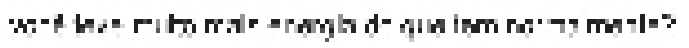

in II II:

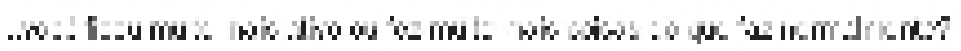

it IT I hid:

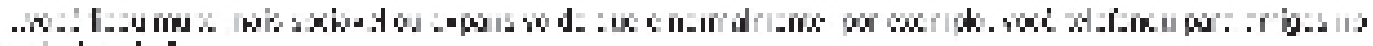
in distis

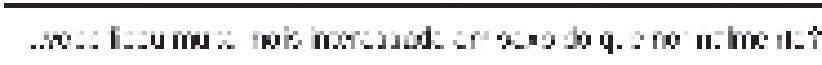

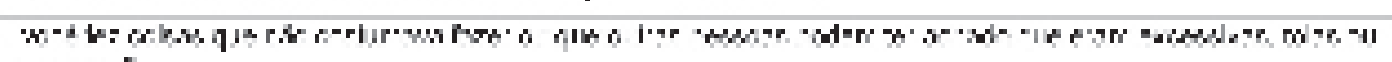
ntratist

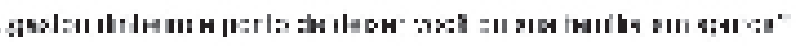

"iri I I H.

7r. I IH.

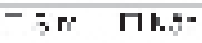

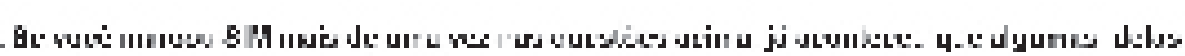

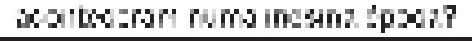

"ir. IIR.A-

- -n Пн."

二

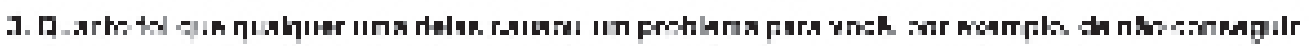

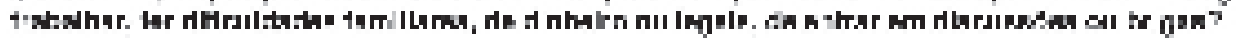

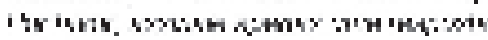

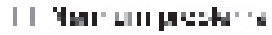

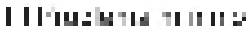

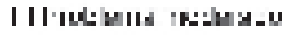

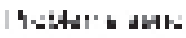

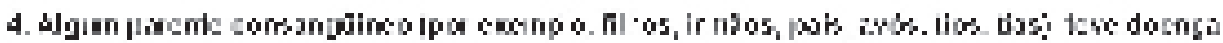

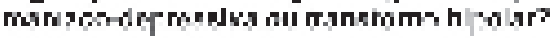

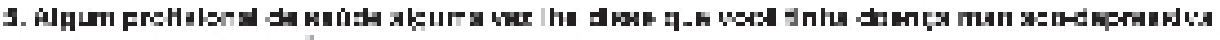

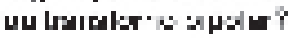

